\title{
Santos y Misterios as Channels of Communication in the Diaspora: Afro-Dominican Religious Practices Abroad
}

Whereas most Afro-Caribbean Creole religious practices have been the focus of scholarly studies for some time, such practices in the Dominican Republic have received considerably less attention. Drawing on ethnographic fieldwork among Dominican women in Madrid and the southwestern Dominican Republic, this article presents the saints of the Dominican Vodou pantheon as actual communication agents who enable transnational practitioners to maintain communication and to solve migration-related problems. These religious practices, including veladas, horas santas, pilgrimages, funeral rites, various healing practices, and spirit possession are strategically used to maintain a transnational community, producing the revitalization of Afro-Dominican religions in the diaspora. Three examples of connection via saints and spirits are analyzed: (1) the use of Vodou to solve visa problems; (2) horas santas to prepare travelers for trips; and (3) the role of saints in narrating migration as a mythologizing experience.

With God and us, you go wherever you want.

Saints talking to Altagracia -Interview, 2001

I was engaged in learning about Second Diaspora people, Haitians whose ancestors were forcibly removed from Africa by slave traders, and who more recently were forced to leave Haiti by poverty and political upheaval. As if that were not enough, these culturally complex people were also actively engaged in trying to make sense of my own culture at the same time and in the same places that I was trying to make sense of theirs.

—Karen McCarthy Brown, Mama Lola

At the opening ceremony of the Dominican Cultural Center in Madrid, in September 2000, a young male Dominican audience member interrupted a lecture on the Taíno, Spanish, and African elements of Dominican Culture, shouting "It's 
time that we call ourselves Blacks, cause WE are black." 1 The audience began to applaud as the lecturer moved on to mention the profound symbolism and importance of the horas santas, los santos or misterios, ${ }^{2}$ and palo music. ${ }^{3}$ Indeed, a year later, the Brotherhood of the Holy Spirit of the Congos in Villa Mella and their palo music were declared by the UNESCO a masterpiece of the oral and intangible heritage of humanity. ${ }^{4}$ The word "Vodou" was not pronounced in that event-and it does not appear in the UNESCO description of the brotherhood that received the award. It is, however, the word employed by most of the researchers who study Afro-Dominican Creole religions, although practitioners prefer the expression creer en los santos, seres, $o$ misterios (we believe in saints, beings, or mysteries). In this article, I focus on those seres as actual communication agents that enable transnational practitioners to maintain their links and to solve migration-related problems.

Whereas Afro-Caribbean religious practices have been the focus of scholarly studies for a long time, these practices in the Dominican Republic have received considerably less attention. The number of monographs dedicated to the topic, for instance, is disproportionate to the number of studies on Santería, Palo Monte, Haitian Vodou, Brazilian Camdomble, or Umbanda, and, unfortunately, there is no uniformity in the ways scholars refer to this aggregate of religious practices. Some anthropologists_-including Martha Ellen Davis (1987, 1996), Carlos Esteban Deive (1974, 1981, [1979] 1996), June Rosenberg (1979), and José Francisco Alegría-Pons (1993)—talk about "Dominican Vodou" to describe these practices. Others, such as Dagoberto Tejeda Ortiz (1998), refer to it simply as "folk religion" because of the deep intertwining of Catholicism and African religions. ${ }^{5}$ In fact, the syncretism with Catholicism in the Dominican Republic is higher than in Cuban Santería or Haitian Vodou, where there is a more structured religious system already in place. ${ }^{6}$ According to Davis,

En Haití la religiosidad popular es el vodoun; cuando se dice "vodoun" se está refiriendo a la religiosidad popular haitiana, con poca excepción. Mientras que en la República Dominicana la religiosidad popular abarca el vodú, entre otros tipos de organización y manifestación. Por ejemplo, la peregrinación, la cofradía afrodominicana, otros tipos de hermandad, la velación de santo- todas estas organizaciones o actividades y otras pueden perfectamente no exhibir el elemento más caraterístico voduista: la posesión espiritual. No obstante, el vodú puede coocurrir con estas otras manifestaciones, si éstas son organizadas o asistidas por "servidores de misterios." (Davis 1987:66-7)

[In Haiti, the folk religion is Vodoun; when somebody says "Vodoun," it means, with few exceptions, "Haitian folk religion." While in the Dominican Republic, folk religion incorporates Vodou, among other types of manifestations and organizations, such as pilgrimage, Afro-Dominican brotherhoods, other kinds of brotherhoods, and velación de santo. In all of these activities or organizations, the most characteristic element of Vodoun (the spiritual possession) might not appear. However, Vodou might appear in all these manifestations if they are organized or assisted by "servers of mysteries."] $]^{7}$

"Folk religion" in the Dominican Republic is often used in scholarly works as a synonym for folk Catholicism, and such a definition might incorporate Vodou practices among 
a variety of organizations and activities (Davis 1987:75). Various religious manifestations, such as pilgrimages, brotherhoods, or funeral rites, might or might not include Vodou elements, depending on whether porters of mysteries participate in these events. According to practitioners, however, there is a continuum among the different practices, and they would never actually refer to the trance states as "Vodou."

The fact that practitioners themselves do not use this term can be partially explained by the political uses of African (or anti-African) heritage in the construction of a fictionalized Dominican national identity. Although the Dominican Republic shares the same history of creolization and colonization as the rest of the Caribbean, it has certain historical particularities, including its plantation structure, its border with Haiti, and its specific independence struggles. In other Latin-American countries, the collective national identity developed in opposition to the colonizers, first the Spaniards and then the North Americans. In both cases the colonizers were male and white. Hence, the intellectual elites of these countries began to search for their indigenous and African roots. In the Dominican case, however, the absolute perceived "Other" was the Haitian. The Taíno Indian population was completely wiped out by the Spaniards after a few years, and anything African was presented by the Spanish elites as related to their Haitian neighbors. As Ninna Sørensen points out, there are new "others" being created all the time in the diaspora (1993). The topic of "Dominican racism" has been treated from various perspectives. I divide the literature on the topic into three groups: (1) works by social scientists who analyze political and academic discourses from the right aimed against blacks and the uses of racial categories to exclude the black population from Dominican elites (Deive 1999; Franco Pichardo 1997, 2001; Sagás 2000); (2) works that incorporate an analysis of folk discourses regarding racial categories (Sørensen 1993, 1997); and (3) works that incorporate both types of discourses (Howard 2001). Problems arise when the reader is induced to think about "Dominicans" and "Dominicanness" in black-and-white terms or when conclusions about the political discourses from the right are applied to Dominican society at large. Sørensen confirms this problem by pointing out that the "theoretical concepts held by researchers have been insufficient for grasping the specific ways in which Dominican people created, constituted and changed their self-perceptions" (1993:32).

By the end of the 1970s, intellectuals began to include African heritage as part of their academic discourses (Deive 1974; Davis 1976; Rosenberg 1979), ${ }^{9}$ and in the past few years various monographs have been dedicated to the topic of antihaitianismo in the Dominican Republic. Ernesto Sagás, for instance, focuses on race and politics, discussing the rejection of the African part of their heritage and arguing that, "like the Spanish, the elites of Santo Domingo thought that they were white (at least somatically speaking), Catholic, and had a Hispanic culture. The Haitians, on the other hand, represented the opposite (and the worst of traits): they were black, they practiced voodoo, and they had an African culture with a thin French veneer" (2000:28-9). Likewise, David Howard, in Coloring the Nation: Race and Ethnicity in the Dominican Republic, explains that,

In order to varnish their common African past, the Dominican people essentially dropped the words black and mulatto from their vocabulary and replaced them with 
the less traumatic and more socially desirable indio. The terms black and mulatto were instead often used to refer to Haitians, who were considered truly black. The indio myth became so widespread that even a black nationalist like Gregorio Luperón referred to the mixed race of the Dominican people; a race that, by the effect of climate, would turn back into that of the original inhabitants of the island (that is, the Indians). More than ever, the pro-Hispanic Dominican elites felt that theirs was a unique race. (2001:35)

Sagás similarly relates the use of the term "indio" (meaning "mulatto") to the indigenismo movement (2000:35). Another reading of the racial term, however, is provided by Sørensen, who strongly argues against those who misinterpret the term "indio" as belonging to the Indian race. She suggests that because "Taíno" became a vacant category, the usage of Taíno symbols is a strategy of resistance and a way of localizing "Creole identity as opposed to national identity on the island" (1997:305). Sørensen, however, also omits the second part of this usage, finding that the word "indio" means brown color and it is implicit that, "if I'm indio, I'm not black, because black is the 'other." "Therefore, "indio" means dark skin, but not black.

Ginetta E. B. Candelario also disagrees with explanations of the rejection of African heritage, but for different reasons:

Is not an overly facile critique of Dominican identity paradigms reinforcing the implicit notion that African ancestry is a "taint" which cannot be escaped? Why aren't Dominicans, who have in the last two centuries absorbed various European and Middle Eastern ancestries, criticized for not considering themselves French, Spanish, Lebanese, Italian? .. . If we said that race is another of the norms of cultural viability, as I believe we can, could it be that the Dominican paradigm and self-identification system is so disturbing to observers because it is perceived as an assault on racial ordering which refuses the subterfuge of passing, an assault which is flamboyant, unremarked, unabashed, indeed, unawares. Because if Dominicans can be white, then who can't? (1999:100-11) ${ }^{10}$

Despite this, Candelario herself recognizes that the rejection of blackness responds more to questioning whether whiteness and blackness are ascribed or achieved statuses and not whether they should be statuses at all, which would be the corollary of her previous questions (1999:112).

Following this necessary digression as to the construction of ethnicity in the Dominican Republic, I turn to the analysis of saints as a channel of communication, leaving aside the subtleties of the invention of Dominican-ness national and transnational identities. This study is based on my fieldwork in Vicente Noble, a town in the southwestern Dominican Republic, and in Spain, focusing on the ways in which narrating was used as a strategy for the creation of locality and agency among Dominican women in Madrid (Sánchez-Carretero 2002). Until 1999, Dominican migration was essentially female, dedicated to domestic work, and, in the case of Madrid, coming from the southwest of the Dominican Republic. Migration networks were formed on kinship, friendship, and godmother relationships. This situation provided a way for many women from Vicente Noble, between the ages of twenty-five 
and fifty-five, to travel to Madrid, specifically to the suburb of Aravaca north of the city, for available domestic work. The cyclical mobility of these transnational families is reinforced by religious links, Afro-Dominican Creole religions being an important presence among them.

In Vicente Noble there are two highly regarded healers/"porters of mysteries" with working centers: Dolores Santos and Juanvé González. Among the different events organized by the practitioners of Dominican Vodou, I mention velaciones (or veladas, as they are called in Vicente Noble, although I have found no written uses of this term), horas santas (or Holy Hours), pilgrimages, funeral rites and services, and other healing practices. The veladas are celebrations dedicated to a specific saint, either because of a promise made or because it is the patron saint of the town. These events can last all day long and into the night. In these celebrations, palos or atabales (drums) are required, accompanied by güiros, and sometimes mandolin and accordion. The horas santas are shorter than veladas. These services usually start in the evening with praying the rosary, singing salves, and optionally, afterward, playing palos. Pilgrimages are organized in groups, such as the pilgrimage to the Virgin of the Remedies or the Virgin of the High Grace (Altagracia). Funeral rites include the novenario (nine days of prayers), with the most important prayer, el rezo, occurring on the ninth day.

Although these practices are often deeply truncated when migration begins, they do not disappear, but rather continually reactivate in various ways in new locales. ${ }^{11}$ First, practitioners keep in contact with the porters of mysteries by using the phone, and, second, when necessary, a mystery (saint or spirit) is sent by the porters to help them out. The two primary vehicles Delores uses to contact her clients abroad are the telephone and her dreams, whereas Juanvé usually receives news from the family members of the migrant who remain in Vicente Noble. ${ }^{12}$ Thus, if a person has a problem in Madrid, for instance, her relatives visit Juanvé, and he sends a transatlantic saint. In addition, the faithful who have had any conflict with the saints try to solve them during their visits to Vicente Noble. This was the case of Milandina Matos, who has been living in Madrid since 1997. Even before her first trip to Spain, the "mysteries started to ride on her," but she had not yet been baptized. ${ }^{13}$ In December 2000, Milandina went back to Vicente Noble to try to "accommodate" the mysteries, because the situation with her job as an interna, a live-in household domestic worker, was becoming unbearable. The spiritual channel was open from the beginning of her trip because Milandina was one of the helpers at Dolores's center before migrating, and she communicated frequently with her spiritual advisor. Milandina's physical presence, however, was a necessary condition for her to be baptized, one reason to speed her return to the Dominican Republic (field notes, January 13, 2001).

Vodou ceremonies have taken on new strength in recent years as many of the horas santas are organized by residents living abroad. There are considerable expenses involved in organizing a velada or a hora santa: food, drinks, and offerings to the saints (plus some money for the paleros [drummers] in case they are not brotherhood members). Vicente Noble is experiencing an incipient case of revival and reinvention of vernacular practices as a result of the move into the diaspora. 


\section{Dominican Vodou and Employment Issues}

Focusing more directly on the saints or mysteries as channels of communication, I start with the healer/porter Juanvé González, who sends spirits to Spain for three main reasons: (1) to facilitate the paperwork to get visas (prior to travel); (2) to help Vicentenoblens get jobs upon their arrival in Madrid; and (3) to help them recover their "five senses." 14

Spirits have a great deal of mobility. Both Dolores and Juanvé have been asked about the success of migration decisions, not only to help workers get visas, but also, as Juanvé says, to see and understand the light: "Primero, tiene que, esa persona vamos poniendo, a lo que la luz indica, lo que la luz dice y lo que la luz habla, lo que la luz responde y lo que la luz divulga. Son los reglamentos y los mandamientos de la ley de Dios asegún usted reconcentra sobre este centro para, vamos poniendo, pa' cuestión de viajes" (Interview, January 29, 2001). (First, that person, let's say, has to see what the light indicates, what the light says, what the light talks, what the light answers, and what the light spreads. These are the regulations and the Ten Commandments, let's say, about traveling.)

Any extra help is well received and, in addition to the paperwork, the religious world strengthens the possibilities of success:

Una persona que lo quiere ayudar a usted, usted sabe, usted le dice y esa persona, vamos poniendo, le dice, "bueno, yo quiero que me de una ayuda" y esa persona que está en España le da la ayuda. Le dice a usted: "bueno, arregle sus papeles que yo le voy a mandar a buscar." Si esa persona se dilata, vamos poniendo, por dos meses, o tres meses, o cuatro meses. $Y$ usted arregló los papeles y esos papeles se los llevaron y de ahí esos papeles los tienen aplastaos abajo de los otros ... de aquí se le envoca [sic] un misterio, usted sabe, se le envía un misterio pa' que movilicen los papeles de allá abajo y los pongan arriba, usted oye, pa' que tengan llamada sobre de usted. Porque si no es así, no hay llamada, porque poniendo papeles sobre papeles, nunca lo van a llamar, nunca van a hallar los papeles suyos, eh. Entonces de ahí se le da la movilización por medio, para jalar esa persona que le va a dar la ayuda, entonces se le pone trabajo de candil, usted oye, se le pone trabajo de candil, para mandar un misterio sobre los cinco sentidos de esa persona, pa' que tenga pensamiento sobre de usted a movilizar esos papeles más a la carrera que al paso y que tenga llamada inmediatamente sobre de usted, cuando tenga llamada sobre de usted, entonces es que usted tiene que venir aquí, "Ah, Juanvé, el trabajo está resultando porque ya me llamaron.” De ahí, si esa persona lo llamó ahora en este mes y en el otro mes no lo llama, se le da otra movilización, ¿pa' qué?, pa' que vamos poniendo le diga en el tiempo, vamos poniendo, que usted se va a ir y le llega la visa, usted sabe. Cuando le llega la visa, tiene que venir aquí, pero primero, antes de tener pensamiento de usted salir, tiene que tirarse una consulta, usted sabe. Cualquiera cosa que tenga sobre su cuerpo, cualquiera tiranía, cualquiera traición, cualquier julepe, cualquier atrabanco que haiga por enmedio, o cualquiera persona que le tire a usted, o que le lleve lo suyo chequea'o, o quiere que viva por el suelo, en este sitio se ve en la luz, entonces ahí se le envoca, vamos poniendo, a esa persona que le tiran a usted, se le envoca a un misterio pa' ponerlo a una distancia lejos. Que no tenga camino, ni 
tenga momento, ni tenga sosiego, ni de sentarse en silla ni de acostarse en cama, ni hacer sus oficios domésticos durante no haiga retiración sobre de usted. Usted oye, entonces de ahí pa'lante, entonces de ahí usted tiene claridad, complicarle una friega, pa' como lo mande el cuerpo, llevar particular todo lo que haya diferente en contra sobre su cuerpo y en contra sobre su pensamiento, se le da retiración, usted sabe. ¿Por qué se le da retiración? porque hay muchas personas que usted con vivir bien ya el tiran, con usted comerse un pedazo de plátano le tiran, con usted tener, vamos poniendo, con usted caminar de aquí pa' ya, le tiran. Y por eso es que hay muchos fracasos así. (Interview, January 29, 2001)

[A person wants to help you, you know, and you tell that person, let's say, you tell her "Well, I want you to help me." And that person, who is in Spain, helps you out. She says "Well, get your papers ready, 'cause I'll get you here." If that person is delayed, let's say, two, three or four months, and you had your papers ready, but they are at the bottom of a pile ... a spirit is invoked, so the documents are mobilized, and get at the top of the pile, so you are called. Because if they keep on putting papers on top of papers, you will never be called. Then, another mobilization to call the person who is going to help you, with a candle work, you hear me? A candle work to send a mystery over the five senses of that person to make her think about you, more in a hurry than in slow motion. So when you receive a call, then it is the moment to come here: "Ah, Juanvé, the work has been a success because they already called me." From there, if that person calls you this month and does not call you the following, I'll give another mobilization. What for? Let's say ... you are ready to leave and your visa arrives. When the visa arrives you have to come here, even before having in mind to leave, you have to come here for a consultation. Anything you might have on your body, any tyranny, any julepe, any knot there might be in the middle, or any person who might throw bad things at you, or follow you, or want you to live on the floor ... I can see it in the light [of the candle]. So I invoke-to that person who pulls you - a mystery to keep her in a distance: so she will not have a path, or a moment, or tranquility, or peace to sit on a chair, nor to sleep in a bed; or to attend her house while she does not leave you in peace. From that moment on, you will have clarity; I'll prepare a rub for your body, to take out anything against your body or your thought. Why do I need to take that out? Because there are many people who throw bad things to you just because you have a good life, just because you eat a plantain, let's say, just because you walk from here to there.... And that's the reason for many failures.]

As is evident in Juanvé's testimony, the different ways to reach the goal of getting the visa are not incompatible but complementary. Juanvé uses the term "mobilization" to refer to the sending of mysteries: "If that person calls you this month and does not call you the following, I'll give another mobilization." The spiritual beings are mobilized along with the object of the petition, in this case the visa documents, which climb from the bottom of the pile to the top: "And you had your papers ready, but they are at the bottom of a pile ... a spirit is invoked, so the documents are mobilized, and get at the top of the pile, so you are called." Liliana Suárez Navaz also brings attention to the ritualization involving the availability of documents and the commercialization of becoming a resident and a citizen. What Suárez Navaz calls "document fetishism" is taken ritually a step further among mystery porters in Vi- 
cente Noble (2000). In comparison, Juanvé's discourse can be analyzed in relation to the fetishism of documents, as he makes accessible various resources to achieve what is considered to be the magic key to solve the immigrant's problems. The repetition of expressions, such as "mobilization," and the synonymy-for instance, "have a path, or a moment, or tranquility, or peace ..." or "anything ... any tyranny, any julepe, any knot"-resembles formulistic lawyers' slang and is used in many instances to avoid silence in his rhythmic monologue. It is interesting to notice that Juanvé does not employ a discourse of victimization that focuses on a dominanted-dominator dichotomy to explain power relationships. On the contrary, he merely explains the strategies that become part of his protocol of performance in the cases of Dominicans abroad.

\section{Horas Santas and Migration}

Another example of religious beliefs linked to spatial mobility is the hora santa honoring Saint James that was organized at Dolores's center. This particular event was a result of a promesa made by Dolores's nephew, Kelvin, prior to his trip to Spain. Dolores described the hora santa in this way:

Le vamos a hacer una hora santa al patrón San Santiago porque a través de él, ese sobrino mío que es el que se va a marchar ahora a España le pidió a él con tal de él irse, de lograr irse allí por medio de su madre que está allá. Y entonces ahora ya se le ha concedido y un día antes de él viajar, de él saber que ya tenía el visado, vino la Metre Silí, y dijo que decía el patrón San Santiago que ya él estaba a punto de viajar y que el quería que le hiciera una hora santa antes de viajar porque si no, no lo dejaba y entonces al otro día de decirle la Metre Silí esto lo han llamado para decirle que ya el visado estaba ahí. Entonces él con mucho gusto pidió dinero a su madre para hacerle la hora santa. (Interview, January 3, 2001)

[We are having an hora santa to honor Saint James because through him, this nephew I have, who is going to leave very soon for Spain, prayed to him to go with his mother, who is there. And now that he gave Kelvin what he asked for, a day before he got the visa, the Metre Silí came and said that Saint James told her that Kelvin was going to leave very soon, and he wanted Kelvin to prepare a hora santa before leaving, because if not, he wouldn't allow him to leave. And then, a day after the Metre Silí told him that, he received a call saying that he had the visa ready. So he happily asked his mother for money to have the hora santa.]

In my interview with Kelvin, he describes his promise in this way: "Yo le dije 'si usted logra que mi mamá me lleve para allá le pongo la promesa' y como lo ha logrado se la voy a poner ahora" (January 3, 2001). [I told him, "If you can make my mother take me there, I'll make a promise," and, as he has kept his word, I'll keep mine.] This sixteen-year-old young man arrived in Madrid in January 2001 but began preparing for his trip almost a year earlier. Explaining that Saint James is his protector, Kelvin says, "Tengo relaciones con él desde que estoy pequeño. Estoy bautizado por él. . . .Tengo muchas relaciones con él. Cada vez que el sube así en cada velada 
que hay me saluda, me da una bendición, él es muy bueno conmigo" (January 3, 2001). [I have a relationship with him since I was a kid. He baptized me.... I have a strong relationship with him and every time he comes up in a velada, he says hello, blesses me ... he's very good to me.] When asked how Saint James was good to him, Kelvin's answer was brief and clear: "Ha hecho muchas cosas. Mira, ha hecho el sueño de mi vida, que mi mamá me quiera llevar para España. Ha hecho mucho por mí él" (January 3, 2001). [He's made a lot of things, he made my mother want to take me to Spain. He made a lot of things for me.] Because Saint James is the patron saint of Spain, it is significant that Kelvin picked him for this event. Nevertheless, I was told that, in horas santas for other people traveling to Spain, different saints were chosen for protection. For example, some choose Santiago, who is "Ogún Balenyó," chief of the division of the Ogún and Metre Silís husband (Virgin of the Sorrows). $\mathrm{He}$ is the saint of thunder and storms, rides a white horse, is usually in love, smokes a lot, and drinks rum—although he is also offered Dominican red wine called "White Horse." ${ }^{15}$ According to Lundius and Lundahl, Saint James, on the other hand, "is the defender of the weak and people without legal knowledge or protection. He is invoked as an advocate in legal disputes and is even considered to be a procurer of United States visas" (2000:286). ${ }^{16}$

Kelvin's hora santa had the double purpose of thanking Saint James for having helped in getting his visa, as well as asking for protection for his trip. The process started with a salve, a song type that is the focus of Davis's ethnomusicological study, Voces del Purgatorio (1981). In this work, Davis argues that the salve is the most widespread musical genre on the island: "Parece que la salve es más típica de la República Dominicana que el propio merengue, puesto que, por lo visto, la salve está más ampliamente difundida por el país y así ha estado durante más tiempo" (1981:25). [It seems that the salve is more typical from the Dominican Republic than the meringue itself, because salves are more widely spread in the country and this has been the case for a long time.] Salves are almost unknown outside of the country, however, because of their religious performative context, although the performances of salves can vary from a rigid structure to complete improvisation and their variations take place in the continuum of two extremes of style: those more sacred, at one end, and those with fewer religious references, at the other.

The textual base of salves is the Salve Regina; its performance contexts include the velaciones, horas santas, and pilgrimages. In Kelvin's case, the salves sang during his hora santa belong to the type named by Davis as "salve with verses," or a type of salve in transition. These salves generally start with the chorus; each stanza has two lines from the Salve Regina and two from the chorus. In Kelvin's ceremony, two salves dedicated to Saint James were sung first, followed by salves honoring other saints:

Salve "Oh San Santiago"

Oh San Santiago

Oh San Santiago

con su caballo

yo beso el mar

y lo apateo y me voy
SAlve "Yo iba caminando"

Yo iba caminando

y de lejos oí una voz

y él era San Santiago,

San Santiago me llamó 
Digan Dios te salve

Dios de reina y madre

de misericordia

yo beso el mar

y lo apateo y me voy

Oh San Santiago ...

Digan Dios te salve

a ti te llamamos

todos los desterrados

yo beso el mar

y lo apateo y me voy

... [continues for thirty-two stanzas]

[Chorus:

Oh, Saint James

Oh, Saint James

With his horse

I kiss the sea

And kick it, and leave]
Ay a ti suspiramos
Ay gimiendo y llorando
Ay pues en este valle
San Santiago

Yo iba caminando ...

Un valle de lágrimas

ruega pues señora

Ay abogada nuestra

San Santiago me llamó

Yo iba caminando ...

... [continues for twenty-two stanzas]

[Chorus:

I was walking

And I heard a voice from far away

And it was Saint James

Saint James called me $]^{17}$

A solo singer generally performs the stanzas while the others in attendance join with the chorus, all sung without drums or any other instruments. In this case, the salve was performed a cappella, although this type of salve also can be accompanied by clapping (Davis 1981:34). After the salves, drum music (palo music) followed, with songs honoring Saint Martha la Domininadora, Saint James, Metre Silí, and Saint Michael. A special blue scarf was prepared with basil and holy water to be blessed during the hora santa. When Santiago "came up" (i.e., when he occupied the body of Dolores), the saint talked to Kelvin, giving him advice for his trip. A special oil was also prepared. According to Santiago himself (as voiced through Juanvé), for the flight Kelvin had to wear the scarf close to him and have a bath with the oil.

Even though this celebration can be analyzed as a rite of passage for Kelvin, the actual mobilization would start later, bringing a deep transformation to him. Distance and mobility, as imagined by the people from Vicente Noble-both those who remain in their town and those who have migrated-are also narrated in terms of their belief systems, using the saints as actual communication agents. Among practitioners of Dominican Vodou in Vicente Noble, various celebrations can be analyzed in terms of how mobility is imagined. The transatlantic movement is linked to a perception of locality materialized in the new communicative processes favored by the channels of communication in the diaspora (Appadurai 1996:18). According to Marc Augé, in our current "overmodernity" we are living a process by which space is shrinking (1993). This view would support the notion that the capacity of transforming space into place is expanding and that it is necessary to consider the new uses of communication channels utilized by Dominican believers to conduct narratives and to locate expression. 


\section{Mythologizing the Migrant Experience via Saints and Spirits}

Myths, as foundational sacred narratives, have many parallels in the life stories recorded during my fieldwork in the Dominican Republic and Spain. In her study of Dominican migration to the United States, Patricia Pessar describes the act of mythologizing the migration experience: "The act of mythologizing life and struggles in the United States is a social and cultural construction that immigrants, returnees, and those who are left behind create and perpetuate" (1995:16).

Altagracia's life story follows the pattern of a heroic adventure, culminating in her relationship with the mysteries. Since she arrived in Madrid in 1993, Altagracia has simultaneously performed priestess duties in her center and worked at her other "regular" jobs-first as a domestic worker and then in a restaurant. Her opening words locate one of the genres she effectively employs in her life story: "Mi historia es que durante el vientre de mi madre, durante estuve en el vientre de mi madre, mi madre me contó que yo lloré en su vientre. A los tres años salí del lado de mi madre. Me fui a casa de una madrastra. Allí me crié, volví a mi casa a los trece años" (Interview, July 26, 2001). [My story is that while I was inside my mother's womb, my mother told me that I cried in her womb. When I was three years old, I left my mother's side. I went with my stepmother. There I grew up, I returned home when I was thirteen.] Crying inside a mother's womb can be one of the attributes of the hero. Altragracia recreates her story like a heroine in a Greek tragedy: "Que se pongan de acuerdo ellos porque yo no puedo terminar de vivir mi vida así. Yo soy una mujer joven y no me voy a dedicar a vivir esta vida, ¿por qué? ¿qué desean?” (August 8, 2001). [I don't want to end my life like this, they have to think what they do, to make a decision about me, cause I cannot end my life living like this. I'm a young woman, and I cannot live like this. Why? What do they want?]

Altagracia's decision to travel to Spain was determined, as is almost every aspect of her life, by "them," the mysteries. It is particularly interesting to note the influence saints have in Altagracia's personal relationships. As I explain below, however, her capacity to make decisions that differ from what the mysteries tell her demonstrates that this carrier of mysteries controls her actions in different ways. The particular construction of her female identity, though, through her life story and the stories told at her center in Madrid reinforces the idea that Altagracia loses control and gives herself to the mysteries. As Dayan points out in Haiti, History, and the Gods, the lwa do not completely "possess" the horse, whose self is not entirely erased: "You let yourself be taken over by something outside of you, a force you want and don't want, control and don't control, and you get a sense of yourself that you did not have before. And spirits unfold their potential in the lineaments of the human, getting what they did not have before, the material envelope through which they experience life on earth" (1995:72). ${ }^{18}$

Altagracia's life story includes a variety of narratives. Following an experiencecentered approach (Hufford 1982), I categorize these narratives into three types: (1) fully conscious narratives, (2) dream narratives, and (3) possession (trance) narratives. All of these share similar structures and flow from one type to another, making the narratives difficult to disentangle. In some cases, Altagracia explicitly marks the different narrative discourses by saying, for instance, "it was in a dream," when she 
refers to dream narratives, or "the mystery came and said such-and-such, and somebody else told me afterwards," indicating possession narratives in which she justifies how she knows what the mystery said (because the porter of mysteries does not remember anything after the possession). In other cases, markers are not so explicit or completely eliminated. For instance, in the following excerpt, Altagracia tells me a personal narrative in which she has two revelations: ${ }^{19}$

A: Yo era camarera de ahí. Y esa señora me ... no sé por qué me cogió un odio muy fuerte. Y me decía todo lo malo. Yo, callada, hasta que un día yo dije "Yo, Espíritu Santo ¿Por qué tengo que estar pasando por esta, esta mujer por qué me trata de esta manera?" y miré al cielo y yo vi, como cuando ... [se emociona y comienza a llorar]

C: Tranquila, si ...

A: Fue algo tan grande lo que yo vi en el cielo, que a cualquiera se lo digo y me dice que es mentira, pero yo vi como cuando una nube se abrió en blanco y yo dije "Espíritu Santo, yo confío en ti. Sáquenme del lado de esta señora como dé lugar porque esta señora no puedo aguantarla." Y yo le dije a ella: "Con Dios y lo que me acompaña, te voy a hacer ver que me voy donde me da la gana." $Y$ en la noche me confirmaron que me sacaban de mi país...

C: Los misterios ...

A: Me confirmaron los misterios que me sacaban de mi país. Me dijeron: "unas palabras que has dicho están confirmadas 'con Dios y nosotros te vas donde te da la gana.' Te sacamos de aquí.” Me señalaron en el aire un avión que disparaba luces en colores, los siete colores de las siete ... las siete potencias. Dijeron: "en ese avión que va ahí, te vas a España. Ahí te vamos a llevar." Y eso fue por el mes de junio. (Interview, July 26, 2001)

[A: I was a waitress there (in a hotel in Santo Domingo). And this woman, I don't know why, but she hated me very badly. She said very bad things to me. I didn't say a word, but one day I said, "Why me, Holy Spirit? Why should I have to go through this? Why is this woman treating me like this?" and I looked up in the sky and I saw, as if ... (Altagracia starts crying).

C: Calm down ... if you want ...

A: It was so amazing what I saw in the sky, that anybody who listens to it would say it's false, but I saw like a cloud opening into white background and I said, "Holy Spirit, I trust you! Take me, no matter how, from the side of this woman because I cannot stand her." And I told her, "With God and what is with me, I'll make you see that I go wherever I want." That night, they confirmed to me that I was leaving the country...

C: The mysteries ...

A: The mysteries confirmed to me that they were taking me out of the country. They told me: "A few words you said are confirmed 'with God and us, you go wherever you want.' We'll take you out of here." They pointed out a plane in the sky shooting lights of all colors, the seven colors of the seven ... the seven potencies. They said, "In the plane you see over there, you'll fly to Spain. We'll take you there." And that was in June.]

Initially when I listened to this personal narrative, I understood the first vision described by Altagracia (when she looks up in the sky and sees "like a cloud opening into white background") as a dream narrative-a revelation via a dream. When I met 
with her after I transcribed our interview tapes so that we could read them together and go over some details, however, Altagracia confirmed that this was a fully conscious narrative. She then repeated the performance in identical form, even crying at the same point she had a few weeks earlier and repeating word for word some of her sentences. Altagracia had indeed seen the clouds opening into a white background(that was her fully conscious perception at the time, differentiating it from dream narratives and possession narratives).

The second revelation occurs when the mysteries confirmed that what she asked for would be accomplished: "The mysteries confirmed to me that they were taking me out of the country. They told me: 'A few words you said are confirmed "with God and us, you go wherever you want." We'll take you out of here.' They pointed a plane in the sky shooting lights of all colors." ${ }^{20}$ Once again, no markers introduced a change for this to be a "consciously told" genre. It could be a revelation told when the mysteries are possessing her. The vision of the plane with the seven colors, however, offers a subtle marker that this is a dream narrative instead of a possession narrative, a fact later confirmed by Altagracia herself. The lack of straightforward markers to distinguish these personal narrative subgenres-dream and possession narratives-demands that the listener concentrate carefully on Altagracia's stories in order to distinguish the various realms of reality. The transitions between these three subgenres are smooth, reflecting the seamless transitions among these spheres in Altagracia's life in the "living theatre that is Vodou" (Burton 1997:9). ${ }^{21}$ The passage from full consciousness to possession and dream revelation is smoothly integrated in her life as a Vodou priestess, a seamlessness that appears in her narratives as well. The transition constitutes what Victor Turner calls "the subjunctive mood of culture" (Turner 1992:59). ${ }^{22}$ This mood helps us understand the desires, wishes, rejections, denials, and fantasies of a group of people. The idea of "subjunctive mood of culture" can illuminate the narrative process in Altagracia's life story and the lack of obvious markers between dream narratives, possession narratives, and fully conscious narratives. If these subgenres are integrated into narrative discourse, to the degree of representing different moods of looking at reality, the smooth shift from one genre to another does not require more grammatical markers. ${ }^{23}$ Gillian Bennett, in her study of supernatural narratives among women, states that, depending on the audience, some personal narratives can be told as lived experiences (what I call "fully conscious narratives") or as dreams: "When she repeated the story to my mother, however, she told it as a real experience, not as a dream. The factor that altered the story was the audience to whom it was told; nothing else had changed" (1999:16).

By telling her life story, Altagracia reenacts herself as a sacrificing mother who becomes a grandmother at age thirty-one and leaves her children with her eldest daughter in order to work in a hotel. Afterward, her story of sacrifice continues when she is sent to Spain by the mysteries. It is also possible to read all the explicit disempowerment of her self due to the mysteries that appear in her narrative as opposition to the society at large. ${ }^{24}$

Altagracia spoke up for the second time in her life just before she started her migration process to Spain (the first time was when she decided to separate from her husband). She was working in a hotel where her boss did not treat her well. She told 
me (to repeat from her earlier account), "I don't know why, but she hated me very badly. She said very bad things to me." Altagracia one day made her "hidden transcript" become public, which was her particular declaration of war: ${ }^{25}$ "I didn't say a word, but one day I said 'Why me, Holy Spirit? Why should I have to go through this? Why is this woman treating me like this?' " Interestingly enough, Altagracia shared her hidden transcript first with the mysteries. Only afterward did she talk about it openly with her boss: "And I said 'Holy Spirit, I trust you! Take me, no matter how, from the side of this woman because I cannot stand her.' And I told her 'With God and what is with me, I'll make you see that I go wherever I want.' " Her hidden transcript had been rehearsed with the mysteries, and the same speech is brought back to her from the mysteries when they talked that night in her dreams: "They told me: 'a few words you said are confirmed "with God and us, you go wherever you want." We'll take you out of here.' '26

Drawing also on James Scott's work, I have identified Altagracia's remarks as a declaration of war. According to Scott, "The first open statement of a hidden transcript, a declaration that breaches the etiquette of power relations, that breaks an apparently calm surface of silence and consent, carries the force of a symbolic declaration of war" (1990:8). Altagracia was consequently fired from her job as a waitress in a hotel; at the same time, the mysteries rewarded her with her trip to Spain. Therefore, the mysteries, identified by her as weapons of resistance, serve as mediators between her and those who have power over her, supporting the idea that possession can be interpreted (as it has been for a long time) as a weapon of social protest for women and marginalized populations in general (Scott 1990:141).

Afro-Dominican religious practices are increasingly linked to transnational situations, and their revitalization appears intertwined with the concept of race as well as with the incipient interest in reclaiming African heritage. Deive ends his study of identity and racism in the Dominican Republic with these words: "Triste es decirlo pero somos el único país afroamericano en el que no ha surgido un movimiento vigoroso y capaz de adquirir una toma de conciencia que reivindique nuestra herencia africana" (1999:47). [It's very upsetting to say this, but we are the only AfroAmerican country without a vigorous movement claiming our African heritage, a movement strong enough to acquire a new consciousness.] In 1993, Francisco AlegríaPons noted that "publishing anything on Gagá, Vodou, or Blacks is a taboo in the Dominican society” (1993:71). This situation seems to be changing, however, in part through the revitalization of these particular religious practices in the diaspora. In the opening example about the Dominican Cultural Center in Madrid, after the speaker's statement, "'cause WE are black," he mentioned the kind of religious aspects described herein, and most of the audience responded by cheering him. As Peggy Levitt describes it, "beliefs about God are, in some sense, the most transnational concepts” (1998:81). Dominican Vodou, as a home-based, informal, folk practice, remains highly transferable and transnational.

I am not suggesting that every Dominican shares the religious practices described above. Rather I am arguing that spiritual mobility is an aspect that needs to be considered if we are to make sense of the motion of different worlds that has become a way of life for residents of Vincente Noble. For mobility (virtual, physical, and spiri- 
tual) is one element present in the web of cultural practices in which we are all suspended as our global world expands.

\section{Notes}

1. The lecture followed the model presented in Bernardo Vega, ed., Ensayos sobre cultura dominicana ([1981] 1996).

2. The term "mystery" (misterio) refers to the saint (santo), being (ser), or lwa (in Haiti) that might possess — or "ride" - a "porter or server of mysteries." I employ the term "mystery," because it is preferred by my collaborators in the field. Martha Ellen Davis, Carlos Andújar, Carlos Esteban Deive, and Dagoberto Tejeda Ortiz use "lwa" as the generic name; however, my Barahonian collaborators in the field employ "lwa" only to make reference to the Haitian dieties. The porters, or servers, of the saints are also called healers or witches, the former terms preferred by the practitioners. For an interesting study of the terminology of Vodou by practitioners in relation to slavery, see Joan Dayan (1995:65-74). As Tejeda Ortiz explains, "A las personas que presentan manifestaciones extraordinarias mentales-espirituales en el campo mágico-religioso, lo que sería para los parasicólogos 'percepciones extrasensoriales', se les conoce a nivel popular con el nombre de 'Curanderos,' 'Brujos,' 'Portadores' o 'Servidores de Misterios,' que es como realmente a mí me gusta llamarles" (1998:4). [Those who present extraordinary spiritualmental manifestations in the magic-religious field—what parapsychologists refer to as "extra-sensorial perceptions"-are known as "healers," "witches," "porters," or "servers of misteries." The latter is how I prefer to call them.] Davis, however, insists on the mistaken equation between saints and mysteries (1987:128).

3. Palo is a type of drum made locally out of a tree trunk.

4. See the websites of Museo del Hombre Dominicano (http://museodelhombredominicano.org/congos.htm) and UNESCO (United Nations Educational, Scientific and Cultural Organization; see link for "Untangible Heritage" at http://portal.unesco.org/culture).

5. Other related studies include Carlos Andújar Persinal's work $(1997,1999)$ and Jan Lundius and Mats Lundahl's recent study of the Olivarista movement, which includes detailed information about Dominican Vodou (2000).

6. Aware of the criticism of theories of syncretism, I use this term while acknowledging the power structures underneath syncretic processes. As posited by Deborah Wyrick: "Recently, however, researchers have developed more nuanced ideas of syncretism, ideas that position religion not only between history and philosophy but also between global capital and local economies. Representing the orishas and lwas through received imagery of Catholic saints may not be simply reactions to oppression ... [but] a way of appropriating [neo-] colonial power, creating a 'transitive resistance' to that power, and strengthening group identity” (1999:2). See also Margarite Fernández Olmos and Lizabeth Paravisini-Gelbert for a recent synthesis of Creole religions in the Caribbean (2003:7-9).

7. Unless otherwise noted, all translations are those of the author.

8. Davis also points out that "no obstante la aplicación, para propósitos cientificos, del término vodú al culto de la Hispaniola en general, es imprescindible señalar que esta nomenclatura no es la utilizada por los practicantes del llamado 'vodú.' Ellos muchas veces consideran que lo denominado 'vodú' es la religión de Haití, porque, de acuerdo con los prejuicios dominicanos, consideran el 'vodú' como sinónimo de 'magia negra.' En realidad, en la República Dominicana—diferente a Haití y otros países afroamericanos con cultos paralelos-no hay un término general para este tipo de organización religiosa" (1987:64). [Despite the application of the term Vodou—for scientific purposes— to this cult in the island of Hispaniola in general, it is essential to note that this name is not used by the practitioners of the socalled "Vodou." This termed is employed to name the Vodou of the region of Haiti. According to Dominican prejudices, Vodou is considered to be synonym of "black magic." In the Dominican Republic — as opposed to Haiti and other Afro-American countries with similar cults—-there is no general term to name this type of religious organization.]

9. Davis observed this situation two decades ago: "En la República Dominicana apenas se está comenzando a investigar y reconocer el componente africano en la cultura nacional. Se ha retardado hasta 
prácticamente esta década por factores políticos, económicos y socioculturales” (1980:255). [In the Dominican Republic, they are just starting to conduct research and to acknowledge the African components of the national culture. It was delayed until this decade due to political, economic, and socio-cultural factors.] Twenty years later, Ginetta Candelario similarly insisted: "Despite the fact that the Dominican population is predominantly an Afro-European one, Dominicans seem to reject blackness as a racial identity, both at the individual and social levels, regardless of Afro-diasporic skin color, hair texture, facial features, cultural artifacts, folkways and discourse. Indeed, as Martha Ellen Davis has pointed out, Dominicans generally are largely unaware of their African ancestry. For example, surprisingly little work, whether historiographic, anthropological or sociological, has been done on the African diaspora into the Dominican Republic" (1999:101). One of the exceptions to this last statement is Celsa Albert Batista's work on women and slavery in the Dominican Republic (1990).

10. At the end of her work, Candelario acknowledges that the nonblackness of Dominican racial identity is a construction, defining Dominicans in opposition to Haitians: "Dominicans themselves anxiously constitute their own whiteness-however they define it-in relation to those whom are blackened by Dominicans, particularly Haitians, poor Dominicans and other Caribbean islanders. What we have then, is a counterhegemonic project situated within a larger hegemonic system of racialization" (1999:111).

11. For an ethnographic account of a Haitian Vodou priestess in Brooklyn, see Karen McCarthy Brown ([1991] 2001).

12. First names of my collaborators are used throughout because surnames are almost always hidden in rural areas in the Dominican Republic. There is even a saying explaining that the names need to be hidden "in case the devil comes asking for you," making the standard practice of using last names in academic writing extremely artificial. In the transcriptions of interviews with my collaborators, three periods means a short pause, a long pause is specified as any other comment (e.g., [silence]), an ellipsis indicates that material is omitted, and indentation means lines pronounced by different people at the same time.

13. In the Dominican Republic there are three types of baptisms: the public, Catholic baptism; the Afro-Dominican equivalent "echar las aguas" ("the pouring of the water" is performed by a rezadora-a woman who knows how to pray-inside the family with godparents who become compadres and comadres); and the baptism to the mysteries. One does not exclude the others. The first two baptisms are widespread among Vicentenoblenses (both in Vincente Noble and in Madrid), but only people who participate actively in Vodou ceremonies are possessed by mysteries, and therefore, need to have themthe mysteries-baptized. This is the rite by which the initiated becomes a member of the brotherhood and, from that moment on, mysteries ride her body "más suaves" (smoother). Dominican folklorist Tejeda Ortiz explains the baptism in this way: "Después que se han presentado las 'señales' de 'subir' misterios, es necesario el 'bautizo ritual,' a fin de que se puedan controlar los 'luases' y puedan dar consultas a sus seguidores" (1998:5). [After the first signals of mysteries riding somebody appear, a "ritual baptism" is necessary in order to control the lwas, and to perform consultations.]

14. In my interviews in Vicente Noble, health problems were the most frequent explanations for an early return. The first months after the arrival are usually when the body suffers the most stress. According to Juanvé, "Many of them leave us and get out of their minds." As he explained it to me,

De ahí, si una persona sale de aquí, y le está mal que no está trabajando allá, se lo invoco a un misterio de aquí y trabaja ella, que le hablen, le buscan, le, vamos poniendo, le dan ayuda pa' que consiga trabajo. Si, si una persona va allá porque salió de este sitio y allá en el sitio, vamos poniendo, es diferente y se le ha cambiado el juicio, se le aplico una friega de aquí y se le manda, pa' llamarle los cinco sentidos, usted oye, se le llaman los cinco sentidos y llegan verbalmente a sus sentidos y no pierde el juicio, porque hay muchas que salen y se cambian el juicio y se ... hay veces que se vuelven locas. (Interview, January 29, 2001)

[If somebody leaves our town, and something goes wrong, and she isn't working, I invoke a spirit from here; so she works, they (the spirits) look for her, watch out for her, talk to her, enlighten her, let's say, they help her so she can find a job. If, if somebody goes there, because she left us, and let's say, she is 
different and her judgment has changed, I apply a rub from here, and I send it to call her five senses, and it reaches verbally her senses and she does not go out of her mind ... because many of them leave us and go out of their minds, and ... sometimes they get crazy.]

\section{See Tejeda Ortiz, Cultura popular e identidad nacional (1998).}

16. Regarding the presence of Ogún in both the Old and New World, see the collection of articles edited by Sandra Barnes (1989), especially the chapter by Brown on Ogún in Haiti.

17. The last two lines of each stanza in both songs are the last two lines of the chorus. For the rest of the stanzas, the first three lines of "Oh San Santiago," and the first two lines of "Yo iba caminando" are lyrics from the Catholic prayer Salve Regina: "Hail holy Queen, Mother of mercy, our life, our sweetness, and our hope. To thee do we cry, poor banished children of Eve. To thee do we send up our sighs, mourning and weeping in this valley of tears. Turn then, most gracious Advocate, thine eyes of mercy toward us. And after this our exile shows unto us the blessed fruit of thy womb, Jesus."

18. In a recent study dedicated to Vodou in Togo, Nadia Lovell develops the same idea of control and agency via spirit possession. Lovell questions the analysis of possession as exclusively an altered state of consciousness, but rather, as a form of communication "embedded in the semantic negotiation of social meaning" (2002:79). Lovell suggests that spirit possession "is no longer seen as a static reflection of fixed male/female relationships, but rather as a continuous enactment and performance of history, memory and identity" (122).

19. For an analysis of revelations in Dominican Vodou, see Davis (1987:102-8).

20. For a description of colors and Dominican Vodou mysteries, see Davis (1987:284) and Andújar Persinal (1999).

21. Richard D. E. Burton's application of Michel de Certeau's concepts of resistance and opposition to Afro-Creole cultures, as employed in his work, Afro-Creole: Power, Opposition, and Play in the Caribbean, is of particular interest. The author uses the term "resistance" as "those forms of contestation of a given system that are conducted from outside that system, using weapons and concepts derived from a source or sources other than the system in question" and "opposition" as "those forms of contestation of a given system that are conducted from within that system, using weapons and concepts derived from the system itself" (1997:6).

22. Turner used this expression to refer to various possession cults (primarily Umbanda).

23. In fact, these subgenres are a type of ethnic genre because they grow out of Altagracia's explanations. Dan Ben-Amos (1976) discusses the incorporation of the emic point of view in generic distinctions. The ethnic genres are cultural modes of communication, while the analytical categories are ways in which texts are organized by scholars (1976:215), which is also related to Alan Dundes's concept of oral literary criticism (1966). During the 1960s and 1970s, the "genre paradigm" in American folkloristics was the dominant mode of conducting research. Roger Abrahams was one of the first folklorists to incorporate Kenneth Burke's concept of rhetoric as action. Later, in his article, "The Complex Relations of Simple Forms," Abrahams establishes a genre classification based on the distance between audience and performer (1976). Afterward, the changing essence of any generic classification was acknowledged, although genres were still very useful from a didactic point of view. Genres helped to establish borders among cultural artifacts and, therefore, the same divisions helped to question those borders, becoming "blurred genres," an especially interesting area of study. In the past few decades, the tendency to search for objective and empiric classifications has been avoided, whereas other questions related to the theoretical base of the fluidity among categories is put to the front. Instead of trying to make typologies of folk artifacts, folklorists now more often view "genre as an orienting framework for the production and interpretation of discourse” (Bauman 1992:53).

24. Afro-Caribbean religions have been studied as subaltern practices. Spanish anthropologists Fernando Giobellina Brumana and Elda González Martínez define Umbanda (the closest Afro-American- "American" as in "the Americas"—religion to Dominican Vodou) as part of a subaltern culture, which together with Candomble, Kardecist Spiritism, and Pentecostalism, are religious healing practices in Brazil (2000:17).

25. I am drawing here on James Scott's concept of hidden and public transcripts. Scott defines a public transcript as a "way of describing the open interaction between subordinates and those who 
dominate" (1990:2). He uses the term "hidden transcript" "to characterize discourse that takes place 'offstage,' beyond direct observation by powerholders" (4). Using examples from a variety of disciplines and geographical locations, he analyzes the different means of resistance among the oppressed. His assumption is that every subordinate group creates a hidden transcript to critique the dominants behind their backs. The powerful also develop "a hidden transcript representing the practices and claims of their rule that cannot be openly avowed" (1990:xii). As part of the hidden transcripts, this author includes verbal practices such as rumors, gossip, folktales, songs, jokes, as well as nonverbal actions such as gestures.

26. Regarding rehearsals of hidden transcripts that one might want to become public, Scott says, "Who, having been insulted or suffered an indignity — especially in public — at the hand of someone in power or authority over us, has not rehearsed an imaginary speech he wishes he had given or intends to give at the next opportunity?" (1990:8).

\section{References Cited}

Abrahams, Roger D. 1976. The Complex Relations of Simple Forms. In Folklore Genres, ed. Dan BenAmos, pp. 109-34. Austin: University of Texas Press.

Albert Batista, Celsa. 1990. Mujer y esclavitud en Santo Domingo. Santo Domingo: Ediciones CEDEE.

Alegría-Pons, José Francisco. 1993. Gagá y vudú en la República Dominicana: Ensayos antropológicos. San Juan, Puerto Rico: Ediciones El Chango Prieto.

Andújar Persinal, Carlos. 1997. La presencia negra en Santo Domingo: Un enfoque etnohistórico. Santo Domingo: Ediciones UAPA.

1999. Identidad cultural y religiosidad popular. Santo Domingo: Editora Cole.

Appadurai, Arjun. 1996. Modernity at Large: Cultural Dimensions of Globalization. Minneapolis: University of Minnesota Press.

Augé, Marc. 1993. Los “no lugares” espacios del anonimato: Una antropología de la modernidad. Barcelona: Gedisa.

Barnes, Sandra, ed. 1989. Africa's Ogun: Old World and New. Bloomington: Indiana University Press.

Bauman, Richard. 1992. Genre. In Folklore, Cultural Performances, and Popular Entertainments. A Communications-Centered Handbook, ed. Richard Bauman, pp. 54-9. New York: Oxford University Press.

Ben-Amos, Dan, ed. 1976. Folklore Genres. Austin: University of Texas Press.

Bennett, Gillian. 1999. Alas, Poor Ghost! Traditions of Belief in Story and Discourse. Logan: Utah State University Press.

Brown, Karen McCarthy. 1989. Systematic Remembering, Systematic Forgetting: Ogou in Haiti. In Africa's Ogun: Old World and New, ed. Sandra Barnes. Bloomington: Indiana University Press.

__ . [1991] 2001. Mama Lola. A Vodou Priestess in Brooklyn. Berkeley: University of California Press.

Burton, Richard D. E. 1997. Afro-Creole: Power, Opposition, and Play in the Caribbean. Ithaca, N.Y.: Cornell University Press.

Candelario, Ginetta E. B. 1999. On Whiteness and Other Absurdities: Preliminary Thoughts on Dominican Racial Identity in the United States. In La República Dominicana en el umbral del siglo XXI: Cultura, política y cambio social, ed. R. Brea, R. Espinal, and F. Valerio-Holguin, pp. 89-117. Santo Domingo: Pontificia Universidad Católica Madre y Maestra.

Davis, Martha Ellen. 1976. Afro-Dominican Religious Brotherhoods: Structure, Ritual, and Music. PhD. Diss., University of Illinois, Urbana-Champaign.

1980. Aspectos de la influencia africana en la música tradicional dominicana. Boletín del Museo del Hombre Dominicano 13:255-92.

1981. Voces de purgatorio: Estudio de la salve dominicana. Santo Domingo: Museo del Hombre Dominicano.

1987. La otra ciencia: El vodú dominicano como religión y medicina populares. Santo Domingo: Editora Universitaria-UASD. 
1996. Vodú of the Dominican Republic. Gainesville, Fla.: ETHNICA Publications.

Dayan, Joan. 1995. Haiti, History, and the Gods. Berkeley: University of California Press.

Deive, Carlos Esteban. 1974. Cromolitografías y correspondencias entre los loa y los santos católicos en el vodú Dominicano. Boletín del Museo del Hombre Dominicano 4:20-62.

—. [1979] 1996. Vodú y magia en Santo Domingo. Santo Domingo: Fundación Cultural Dominicana.

1981. La herencia Africana en la cultura Dominicana de hoy. In Ensayos sobre cultura Dominicana, ed. B. Vega, pp. 105-41. Santo Domingo: Museo del Hombre Dominicano.

. 1999. Identidad y racismo en la República Dominicana. Santo Domingo: Ayuntamiento del Distrito Nacional-UASD.

Dundes, Alan. 1966. Metafolklore and Oral Literary Criticism. Monist 60:505-16.

Fernández Olmos, Margarite, and Lizabeth Paravisini-Gebert. 2003. Creole Religions of the Caribbean: An Introduction from Vodou and Santería to Obeah and Espiritismo, Religion, Race, and Ethnicity. New York: New York University Press.

Franco Pichardo, Franklin. 1997. Sobre racismo y antihaitianismo: (y otros ensayos). Santo Domingo: [n.p.].

—_ 2001. Ensayos profanos: Sobre racismo, pesimismo e izquierdismo. Santo Domingo: Sociedad Editorial Dominicana.

Giobellina Brumana, Fernando, and Elda González Martínez. 2000. Umbanda: El poder del margen. Cádiz: Universidad de Cádiz.

Howard, David. 2001. Coloring the Nation: Race and Ethnicity in the Dominican Republic. Boulder, Col.: Rienner/Signal Books.

Hufford, David. 1982. The Terror That Comes in the Night: An Experience-Centered Study of Supernatural Assault Traditions. Philadelphia: University of Pennsylvania Press.

Levitt, Peggy. 1998. Local-Level Global Religion: The Case of US-Dominican Migration. Journal for the Scientific Study of Religion 37(1):74-89.

Lovell, Nadia. 2002. Cord of Blood: Possession and the Making of Voodoo, Anthropology, Culture, and Society. London: Pluto Press

Lundius, Jan, and Mats Lundahl. 2000. Peasants and Religion: A Socioeconomic Study of Dios Olivorio and the Palma Sola Movement in the Dominican Republic. London: Routledge.

Pessar, Patricia. 1995. Visa for a Dream: Dominicans in the United States. Boston: Allyn and Bacon.

Rosenberg, June C. 1979. El Gagá: Religión y sociedad de un culto Dominicano: Un estudio comparativo. Santo Domingo: Universidad Autónoma de Santo Domingo.

Sagás, Ernesto. 2000. Race and Politics in the Dominican Republic. Gainesville: University Press of Florida.

Sánchez-Carretero, Cristina. 2002. Narrating Diasporas: Strategies in the Creation of Locality and Agency Among Dominican Women Abroad. Ph.D. Diss., University of Pennsylvania.

Scott, James C. 1990. Domination and the Arts of Resistance: Hidden Transcripts. New Haven, Conn.: Yale University Press.

Sørensen, Ninna Nyberg. 1993. Creole Culture, Dominican Identity. Folk 35:17-35.

- 1997. There Are No Indians in the Dominican Republic. In Sitting Culture: The Shifting Anthropological Object, ed. K. F. Olwig and K. Hastrup, pp. 292-310. London: Routledge.

Suárez Navaz, Liliana. 2000. Inmigración: Irregular, regularizaciones y efectos en la identidad de los inmigrantes. Paper presented at II Congreso Sobre la Inmigración en España, Madrid, October 5-7.

Tejeda Ortiz, Dagoberto. 1998. Cultura popular e identidad nacional. 2 vols. Santo Domingo: Consejo Presidencial de Cultura-Instituto Dominicano de Folklore.

Turner, Victor. 1992. The Anthropology of Performance. New York: PAJ Publications.

Vega, Bernardo, ed. [1981] 1996. Ensayos sobre cultura Dominicana. Santo Domingo: Museo del Hombre Dominicano.

Wyrick, Deborah. 1999. Divine Transpositions: Recent Scholarship on Vodou and Santería Religious Art. Jouvert: A Journal of Postcolonial Studies 3(1-2). http://social.chass.ncsu.edu/jouvert/v3i12/vodou. htm, accessed September 2002. 